\title{
Influence of potassium doping on the activity and the sulfur poisoning resistance of soot oxidation catalysts
}

\author{
Kirill Tikhomirov, Oliver Kröcher,* and Alexander Wokaun \\ Paul Scherrer Institute, CH-5232 Villigen PSI, Switzerland
}

Received 13 February 2006; accepted 24 February 2006

\begin{abstract}
Soot oxidation on potassium nitrate impregnated cerium oxide and manganese cerium mixed oxide was investigated using TG-FTIR. It was found, that potassium nitrate promotes the soot oxidation by enhancing the contact between the soot and the catalyst, as soot ignition temperature corresponds to the melting point of potassium nitrate for both the individual and the mixed oxide. Since potassium nitrate is easier sulfatized than cerium or manganese, the susceptibility of the catalyst to sulfur poisoning is considerably decreased.
\end{abstract}

KEY WORDS: soot oxidation catalyst; sulfur poisoning; potassium doping; manganese cerium mixed oxide.

\section{Introduction}

In order to reduce the costs of diesel particulate filters, numerous cheap noble metal free soot oxidation catalysts have been investigated over the last 20 years. In these investigations it was shown that tight contact between catalyst and soot is crucial for achieving high activity [1]. However, only a loose contact is achieved between soot and catalyst under real conditions in a diesel particulate filter [2]. One option to overcome this problem is to use molten salts as catalytic material [3]. The high mobility of the catalyst at elevated temperatures leads to an intimate contact of catalyst and soot particles resulting in a high catalytic activity even if the soot was not tightly mixed with the catalyst [4]. Alkali metal salts as well as cobalt and lead compounds were used in order to decrease the melting point and to improve the mobility of the catalysts [5-8]. Potassiumloaded lanthana and ceria were proposed for the simultaneous abatement of nitrogen oxides and soot $[9,10]$.

Sulfur poisoning poses another problem for the development of noble metal free catalysts. For instance, ceria and manganese were found to be highly active soot oxidation catalysts due to their oxygen storage ability and strong oxidative properties [11,12]. However, these materials loose their oxidative properties rapidly when exposed to sulfur due to reductive sulfatization. Regeneration requires high temperatures and the catalytic activity is not or only partly recovered due to changes in the catalyst structure $[11,13,14]$.

In the present work we tried to increase the catalytic activity of pure ceria as well as manganese cerium mixed

\footnotetext{
*To whom correspondence should be addressed. E-mail: Oliver.Kroecher@psi.ch
}

oxide by addition of potassium nitrate and investigated the influence of the dopant on the sulfur poisoning of the catalysts.

\section{Experimental}

\subsection{Catalyst preparation and characterization}

$\mathrm{MnO}_{x}-\mathrm{CeO}_{2}$ with a molar ratio of $\mathrm{Mn}: \mathrm{Ce}=1: 3$ was prepared by co-precipitation using acetates of $\mathrm{Ce}$ (III) and $\mathrm{Mn}(\mathrm{II})$ as starting materials as described elsewhere [11]. $\mathrm{CeO}_{2}$ was prepared according to the same procedure using cerium acetate only as starting material. Commercially available titanium dioxide from Kemira $\left(S_{\mathrm{BET}}=140 \mathrm{~m}^{2} / \mathrm{g}\right)$ was used as a reference material.

$\mathrm{KNO}_{3}-\mathrm{CeO}_{2}, \mathrm{KNO}_{3}-\mathrm{MnO}_{x}-\mathrm{CeO}_{2}$ and $\mathrm{KNO}_{3}-\mathrm{TiO}_{2}$ with a molar ratio of $\mathrm{K}: \mathrm{M}=1: 3$ were prepared of $0.03 \mathrm{~mol}$ of the calcined oxides by impregnation with a saturated aqueous solution of $0.01 \mathrm{~mol} \mathrm{KNO}_{3}$. The water was evaporated under continuous stirring and the resulting materials were dried at $120{ }^{\circ} \mathrm{C}$ overnight followed by calcination at $600{ }^{\circ} \mathrm{C}$ for $2 \mathrm{~h}$. For the experiment with different potassium loadings, $\mathrm{KNO}_{3}-\mathrm{MnO}_{x}-$ $\mathrm{CeO}_{2}$ catalysts with molar ratios of $\mathrm{K}: \mathrm{M}=1: 12,1: 6$ and 1:1.5 were prepared using the same procedure.

The specific surface areas $\left(S_{\mathrm{BET}}\right)$ of the prepared samples were determined by nitrogen physisorption at $77 \mathrm{~K}$ (Micromeritics ASAP 2001). Prior to the measurement, the samples were degased at $250^{\circ} \mathrm{C}$. The elemental compositions of the catalysts were studied by means of ICP-AES. $50 \mathrm{mg}$ of each sample were dissolved in $50 \mathrm{ml}$ of a $50 \%$ sulfuric acid solution followed by a dropwise addition of $\mathrm{H}_{2} \mathrm{O}_{2}$ till the solution was colorless. Subsequently, the solution was diluted in the 
ratio 1:10 and $\mathrm{H}_{3} \mathrm{BO}_{3}$ was added prior to analysis with a Varian Vista AX spectrometer.

\subsection{Soot oxidation in TG-FTIR}

Soot oxidation experiments were performed by means of a TGA-DTA/DSC device (Netzsch STA 449C Jupiter) coupled with an FTIR-spectrometer (Bruker Tensor 27 DGTS). Mass loss of the sample, the DTA signal and the $\mathrm{CO}$ and $\mathrm{CO}_{2}$ concentrations downstream of the reaction chamber were measured. The soot used in the experiments was collected from the exhaust of a EURO II diesel engine downstream of a diesel oxidation catalyst to ensure the removal of adsorbed hydrocarbons [15]. The specific surface area $\left(S_{\mathrm{BET}}\right)$ of the soot was measured to be $110 \mathrm{~m}^{2} / \mathrm{g}$. Five milligrams of soot were mixed with $100.0 \mathrm{mg}$ of the catalyst in a crucible with a spatula in order to achieve "loose" soot-catalyst contact being representative for the conditions in a diesel particulate filter $[2,16]$. The mixture was heated from 30 to $700{ }^{\circ} \mathrm{C}$ at a heating rate of $10{ }^{\circ} \mathrm{C} / \mathrm{min}$ in a $140 \mathrm{ml} / \mathrm{min}$ model gas flow of $10 \%$ $\mathrm{O}_{2}, 3 \% \mathrm{H}_{2} \mathrm{O}$ and 1000 ppm NO in $\mathrm{N}_{2}$. Soot oxidation rates were calculated on the basis of $\mathrm{CO}_{2}$ formation rate, being in good agreement with the reaction rates calculated from the sample mass losses. The $\mathrm{CO}$ yield was negligible for all catalysts.

\section{3. $\mathrm{NO}$ oxidation and $\mathrm{SO}_{2}$ poisoning in the flow reactor}

The $\mathrm{NO}$ oxidation measurements and $\mathrm{SO}_{2}$ poisoning experiments were performed in a flow reactor, in which $1.00 \mathrm{~g}$ of catalyst powder was fixed between two quartz wool plugs. The reactor was heated with a heating coil, whereas the temperature was regulated by a PID controller using a thermocouple fixed on the outer surface of the reactor. The temperature inside of the catalyst sample was measured with a second thermocouple. The composition of the feed gas $\left(150 \mathrm{~L}_{\mathrm{N}} / \mathrm{h}\right)$ was adapted to a typical diesel exhaust gas containing $10 \% \mathrm{O}_{2}, 5 \% \mathrm{H}_{2} \mathrm{O}$ and $1000 \mathrm{ppm} \mathrm{NO}$ with balance $\mathrm{N}_{2}$. For the $\mathrm{SO}_{2}$ poisoning experiments $10 \mathrm{ppm} \mathrm{SO}_{2}$ were used instead of NO. Flow rates were regulated using mass flow controllers (Brooks 5850S, 5881). A Nicolet Magna-IR 560 FTIR spectrometer was used to quantify the NO and $\mathrm{NO}_{2}$ concentrations downstream of the reactor.

\subsection{DRIFT investigation of $\mathrm{SO}_{2}$ adsorption}

DRIFT analysis of the adsorbed species was performed at $400{ }^{\circ} \mathrm{C}$ using a Nicolet Nexus 670 FTIR spectrometer equipped with a DRIFT cell. Prior to the adsorption experiments the IR spectrum of the fresh catalyst was recorded as reference. The sample was pretreated with $10 \% \mathrm{O}_{2}$ and $50 \mathrm{ppm} \mathrm{SO}_{2}$ in $\mathrm{N}_{2}$ at $400{ }^{\circ} \mathrm{C}$ for $1 \mathrm{~h}$, followed by the measurement of IR spectra of the adsorbed species in the range from 2000 to $800 \mathrm{~cm}^{-1}$.

\section{Results and discussion}

The BET surface areas $\left(S_{\mathrm{BET}}\right)$ of the catalysts were measured to be $42 \mathrm{~m}^{2} / \mathrm{g}$ for $\mathrm{CeO}_{2}, 83 \mathrm{~m}^{2} / \mathrm{g}$ for $\mathrm{MnO}_{x}-$ $\mathrm{CeO}_{2}, 15 \mathrm{~m}^{2} / \mathrm{g}$ for $\mathrm{KNO}_{3}-\mathrm{CeO}_{2}$ and $22 \mathrm{~m}^{2} / \mathrm{g}$ for $\mathrm{KNO}_{3}-\mathrm{MnO}_{x}-\mathrm{CeO}_{2}$. It can be seen, that potassium nitrate impregnation leads to a significant decrease of the specific surface area. This result was expected due to the low surface area and quite high fraction of potassium nitrate in the final catalyst. The K:M molar ratios measured by ICP-AES were determined to be 1:3.42; 1:3.21 and 1:3.18 for $\mathrm{KNO}_{3}-\mathrm{CeO}_{2}, \mathrm{KNO}_{3}-\mathrm{MnO}_{x}-\mathrm{CeO}_{2}$ and $\mathrm{KNO}_{3}-\mathrm{TiO}_{2}$, respectively. The slightly lower fraction of potassium in the final catalyst in comparison to the fraction in the starting materials can be ascribed to an incomplete impregnation process, as part of the potassium nitrate was forming separate crystallites instead of depositing on the metal oxide surface. Details about the base materials (ceria and cerium manganese mixed oxides) including XRD analysis are reported in [11].

The catalytic activities of the samples for soot oxidation were compared in TPO experiments. The reaction rates for the non-impregnated and potassium nitrate impregnated oxides are shown in figure $1 \mathrm{a}$ and $\mathrm{b}$, respectively. In case of the non-impregnated catalysts, manganese cerium mixed oxide shows the highest activity, followed by cerium oxide and titanium oxide with nearly no oxidation activity. The high activity of
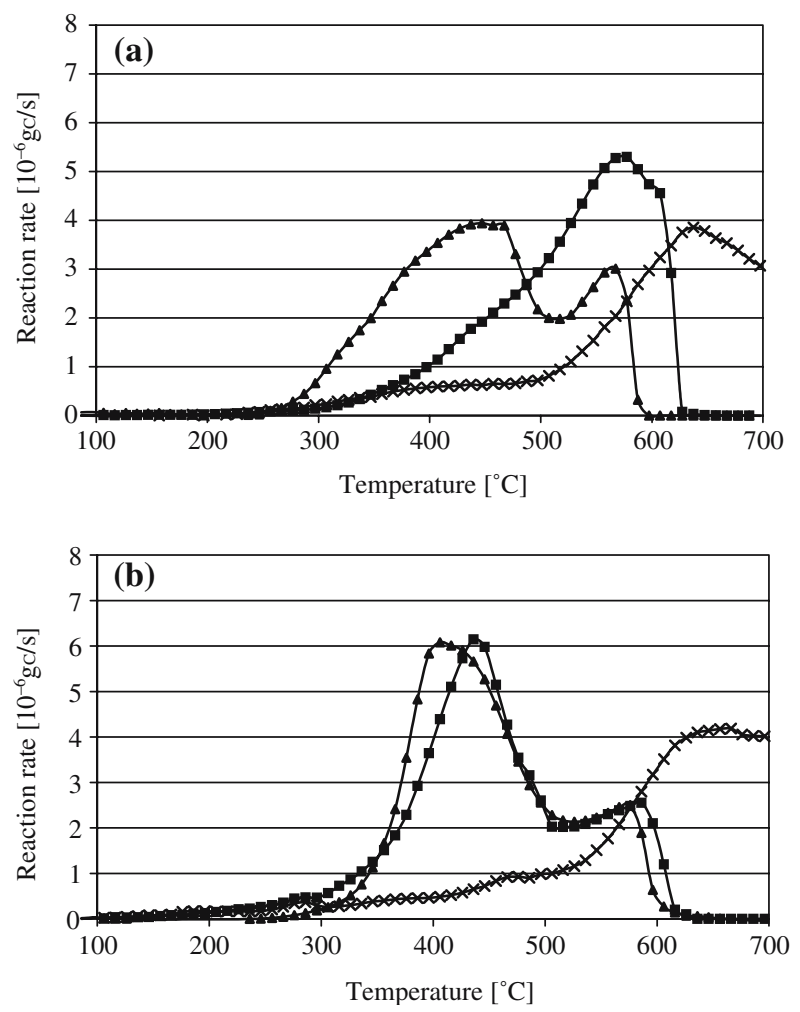

Figure 1. TPO profiles for soot oxidation on (a) undoped and (b) potassium doped $(\mathbf{\Delta}) \mathrm{MnO}_{x}-\mathrm{CeO}_{2}(\boldsymbol{\bullet}) \mathrm{CeO}_{2}$ and $(\times) \mathrm{TiO}_{2}$. Reactant gas: $10 \% \mathrm{O}_{2}+1000$ ppm $\mathrm{NO}+3 \% \mathrm{H}_{2} \mathrm{O}$ in $\mathrm{N}_{2}$. 
the mixed oxide is explained by the higher oxygen mobility [17] as well as by the high contribution of $\mathrm{NO}_{2}$ to the combustion, which is efficiently formed from $\mathrm{NO}$ over the mixed oxide [11]. In pure ceria this two effects are much less pronounced [12]. Titanium oxide does not possess oxidative properties and acts as a reference material here.

Potassium impregnated $\mathrm{CeO}_{2}$ and $\mathrm{MnO}_{x}-\mathrm{CeO}_{2}$ exhibited the same soot ignition temperature of $\sim 330^{\circ} \mathrm{C}$ and approximately the same maximum soot oxidation rate of $\sim 6 \mu \mathrm{g}_{\mathrm{C}} / \mathrm{s}$. However, the maximum oxidation rate was reached at lower temperature for $\mathrm{KNO}_{3}-\mathrm{MnO}_{x}$ $\mathrm{CeO}_{2}$. The impregnation of potassium on inactive $\mathrm{TiO}_{2}$ did not induce any activity change.

Another interesting feature of the soot oxidation over the potassium doped catalyst is illustrated by the results of the TPO experiment with $\mathrm{KNO}_{3}-\mathrm{MnO}_{x}-\mathrm{CeO}_{2}$ catalyst when using different feed gas compositions (figure 2). It can be seen, that the ignition temperature lies at $\sim 330^{\circ} \mathrm{C}$ for all three compositions and the maximum reaction rate is also similar. The peak shoulder between 200 and $300{ }^{\circ} \mathrm{C}$ in the case of $\mathrm{NO}_{2}$ containing feed is caused by the non-catalytic reaction of carbon with $\mathrm{NO}_{2}$ that proceeds at significant rates in this temperature range. Interestingly, adding NO to the feed does not have any influence on the oxidation rate, whereas it plays a crucial role for the non-impregnated manganese cerium mixed oxide, as described in [11].

The similar behavior of the different catalysts $\left(\mathrm{KNO}_{3}-\mathrm{MnO}_{x}-\mathrm{CeO}_{2}\right.$ and $\left.\mathrm{KNO}_{3}-\mathrm{CeO}_{2}\right)$ with different oxidizing feed gas mixtures $\left(\mathrm{O}_{2}, \mathrm{NO} / \mathrm{O}_{2}\right.$ and $\left.\mathrm{NO}_{2}\right)$ can only be explained by the enhanced contact of the catalyst with soot due to the melting of potassium nitrate. This explanation is supported by the fact that the onset temperature of the DSC peak corresponds to the melting point of potassium nitrate and this again corresponded to the onset temperature of the soot oxidation peak in the TPO experiment (figure 3).

Based on the mechanism of soot oxidation over $\mathrm{MnO}_{\mathrm{x}}-\mathrm{CeO}_{2}$ via the oxidation of $\mathrm{NO}$ [11], the influence

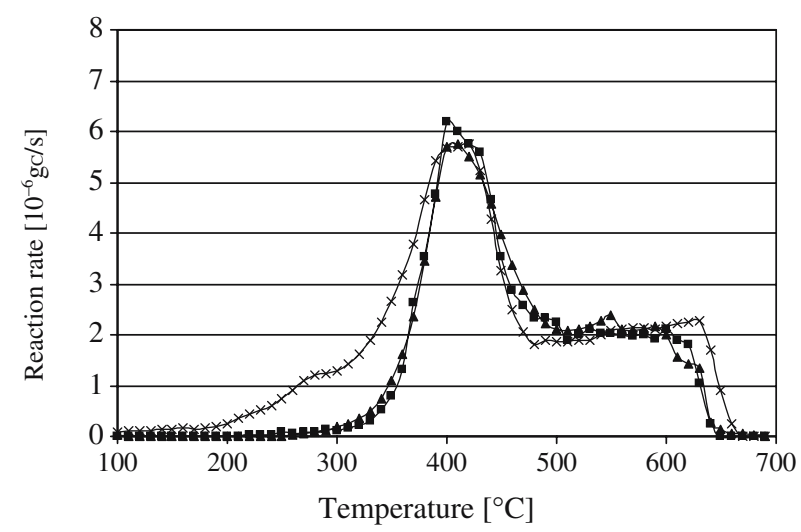

Figure 2. TPO profiles for the soot oxidation on $\mathrm{KNO}_{3}-\mathrm{MnO}_{x}-\mathrm{CeO}_{2}$. Reactant gas: $(\boldsymbol{\Delta}) 10 \% \mathrm{O}_{2}$ in $\mathrm{N}_{2}(\boldsymbol{\bullet}) 10 \% \mathrm{O}_{2}+1000$ ppm NO in $\mathrm{N}_{2}$, (×) $5000 \mathrm{ppm} \mathrm{NO}_{2}$ in $\mathrm{N}_{2}$.

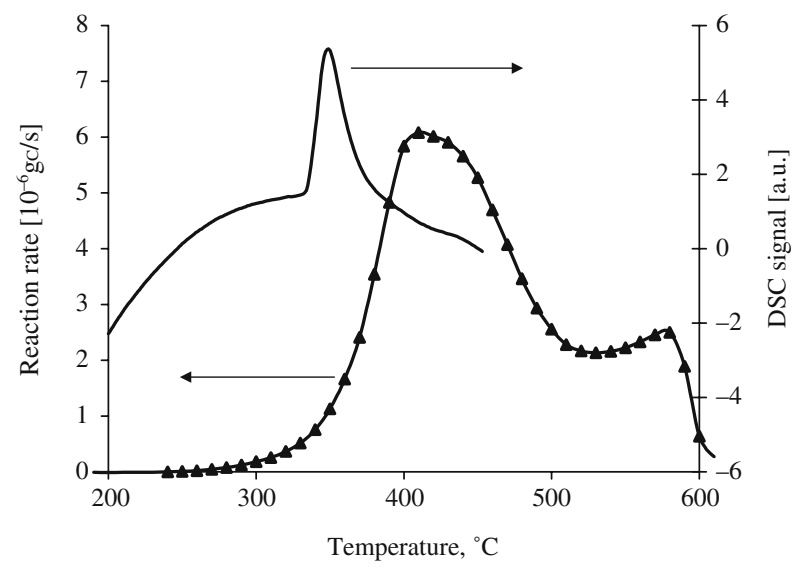

Figure 3. (ム) Soot oxidation rate in a TPO experiment with $\mathrm{KNO}_{3}$ $\mathrm{MnO}_{x}-\mathrm{CeO}_{2}$ catalyst. Reactant gas: $10 \% \mathrm{O}_{2}+1000 \mathrm{ppm} \mathrm{NO}+3 \%$ $\mathrm{H}_{2} \mathrm{O}$ in $\mathrm{N}_{2}$. (-) DSC signal obtained for the catalyst without soot.

of potassium impregnation on the NO oxidation activity was investigated in flow reactor experiments. Figure 4 shows a drastic drop of oxidation activity over the whole temperature range from 150 to $450{ }^{\circ} \mathrm{C}$. This activity drop correlates with the loss of the specific surface area of the catalyst. However, in the soot oxidation experiment, this reduced oxidation activity did not affect the soot oxidation activity due to the predominance of the effect of the increased soot-catalyst contact above the potassium nitrate melting point.

Figure 5 shows almost no difference in soot oxidation activity over a broad range of potassium nitrate loadings on $\mathrm{MnO}_{x}-\mathrm{CeO}_{2}$. Only a slight shift to lower oxidation rates is detectable for the catalyst with the lowest potassium loading $(\mathrm{K}:(\mathrm{Mn}+\mathrm{Ce})=1: 12)$. It can therefore be concluded, that small amounts of potassium nitrate on the surface are sufficient to improve the contact between catalyst and soot.

In order to determine the influence of potassium on the sulfur poisoning behavior of the catalyst, nonimpregnated and potassium impregnated $\mathrm{MnO}_{x}-\mathrm{CeO}_{2}$ were exposed to $10 \mathrm{ppm} \mathrm{SO}_{2}+10 \% \mathrm{O}_{2}$ in $\mathrm{N}_{2}$ for 10

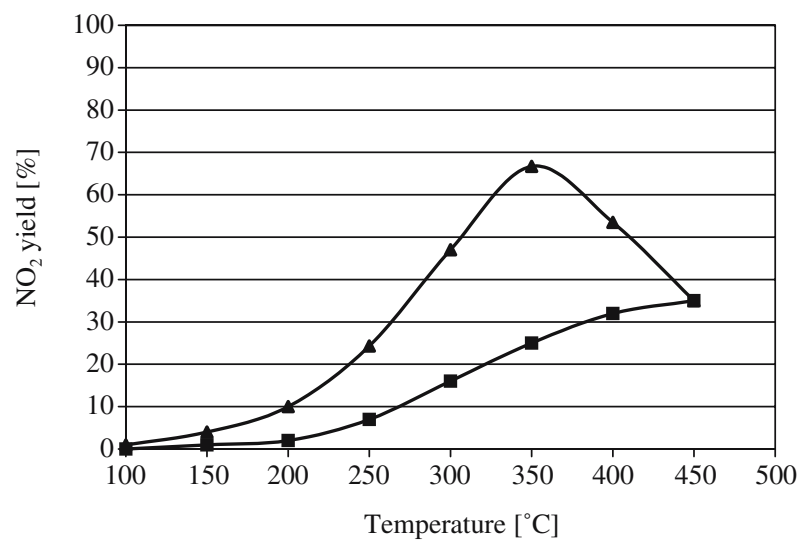

Figure 4. $\mathrm{NO}$ oxidation over $(\boldsymbol{\Delta}) \mathrm{MnO}_{x}-\mathrm{CeO}_{2}$ and (घ) $\mathrm{KNO}_{3}-\mathrm{MnO}_{x}$ $\mathrm{CeO}_{2}$. Feed gas: $10 \% \quad \mathrm{O}_{2}+1000 \mathrm{ppm} \mathrm{NO}+5 \% \quad \mathrm{H}_{2} \mathrm{O}$ in $\mathrm{N}_{2}$. $\mathrm{GHSV}=52,000 \mathrm{~h}^{-1}$. 


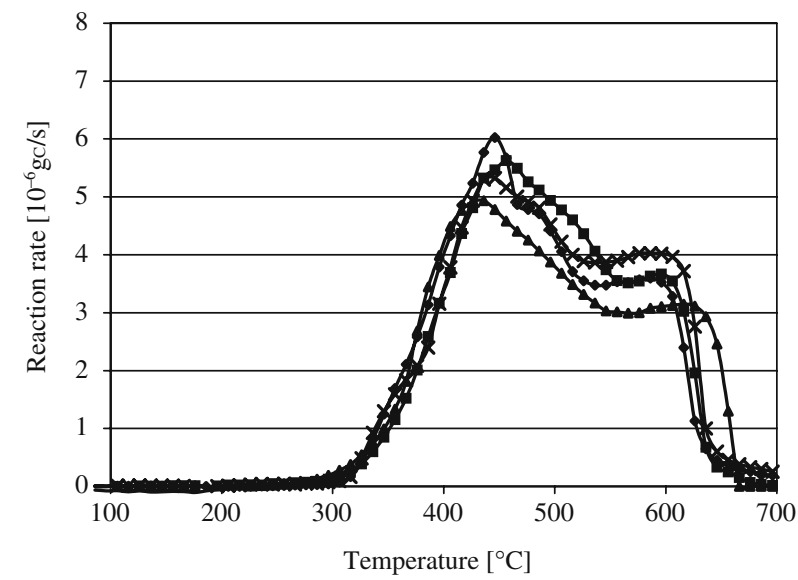

Figure 5. Comparison of the soot TPO profiles for $\mathrm{KNO}_{3}-\mathrm{MnO}_{x^{-}}$ $\mathrm{CeO}_{2}$ with different potassium loadings. $\mathrm{K}: \mathrm{M}=(\mathbf{\Delta})$ 1:12 $(\times)$ 1:6 (Ш) $1: 3(\diamond)$ 1:1.5. Reactant gas: $10 \% \mathrm{O}_{2}+1000 \mathrm{ppm} \mathrm{NO}+3 \% \mathrm{H}_{2} \mathrm{O}$ in $\mathrm{N}_{2}$.

and $100 \mathrm{~h}$ followed by TPO experiments with soot. The TPO curve of the undoped catalyst (figure 6a) shows only a small shift to lower oxidation rates after $10 \mathrm{~h}$ of exposure, whereas almost complete loss of activity was observed after $100 \mathrm{~h}$ of $\mathrm{SO}_{2}$ treatment. This activity loss is due to reductive sulfatization of manganese and ceria causing a drop in oxygen mobility and NO oxidation
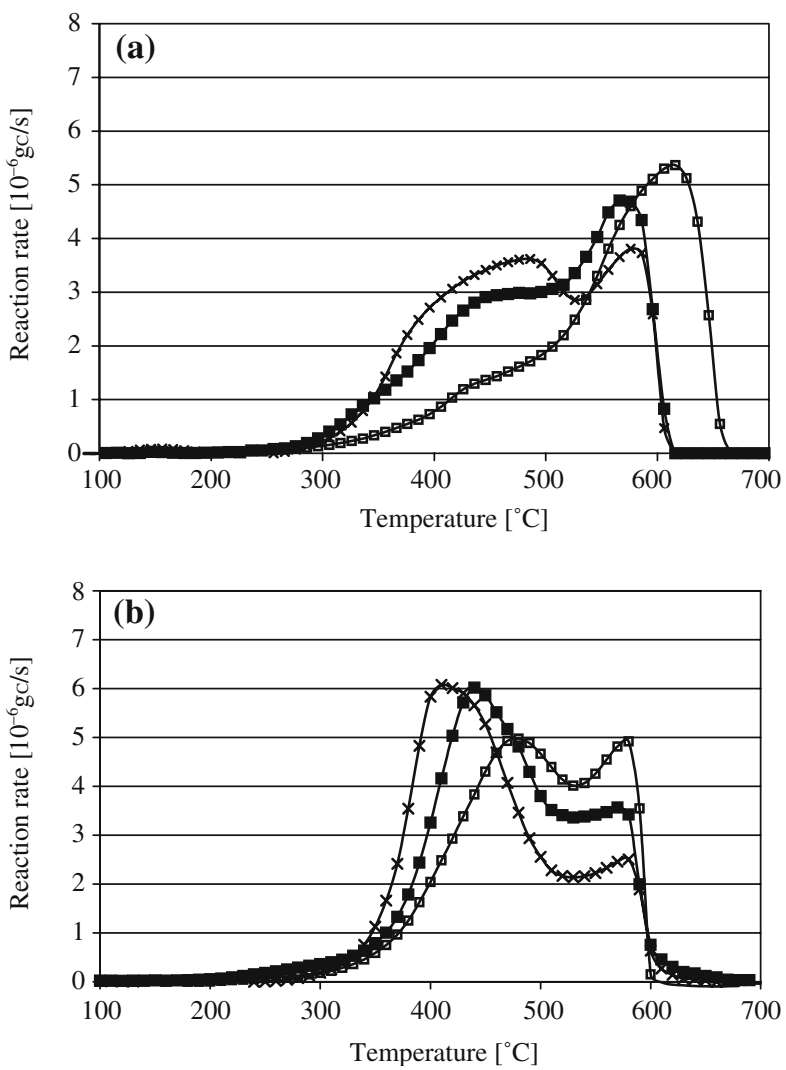

Figure 6. TPO profiles for soot oxidation on (a) undoped and (b) potassium doped $\mathrm{MnO}_{x}-\mathrm{CeO}_{2}$ upon $\mathrm{SO}_{2}$ treatment. $(\times)$ Fresh catalyst $(\square)$ after $10 \mathrm{~h}$ treatment $(\square)$ after $100 \mathrm{~h}$ treatment. Reactant gas: $10 \%$ $\mathrm{O}_{2}+1000$ ppm NO $+3 \% \mathrm{H}_{2} \mathrm{O}$ in $\mathrm{N}_{2}$.

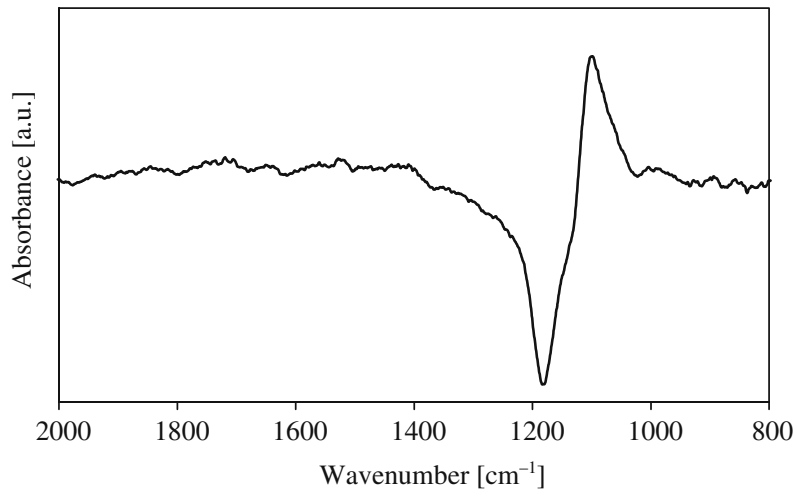

Figure 7. DRIFT difference spectrum of $\mathrm{KNO}_{3}-\mathrm{MnO}_{x}-\mathrm{CeO}_{2}$ after exposure to $10 \% \mathrm{O}_{2}$ and $50 \mathrm{ppm} \mathrm{SO}_{2}$ in $\mathrm{N}_{2}$ for $2 \mathrm{~h}$ at $400{ }^{\circ} \mathrm{C}$.

activity as shown in $[11,14]$. However, the activity loss is much more moderate in the case of the potassium doped oxide (figure 6b). Despite the shift of the TPO curve towards higher temperatures, oxidation activity is still high in the temperature range between 400 and $500{ }^{\circ} \mathrm{C}$ even after $100 \mathrm{~h}$ of $\mathrm{SO}_{2}$ exposure.

The differential DRIFT spectrum of the adsorbed species of $\mathrm{KNO}_{3}-\mathrm{MnO}_{\mathrm{x}}-\mathrm{CeO}_{2}$ catalyst before and after $\mathrm{SO}_{2}$ treatment exhibits a positive peak at $1100 \mathrm{~cm}^{-1}$ and a negative peak at $1190 \mathrm{~cm}^{-1}$ (figure 7). The positive peak corresponds to the formation of potassium sulfate, whereas the negative indicates the simultaneous disappearance of potassium nitrate. This result indicates the preferential sulfatization of potassium in comparison to cerium and manganese, as no peaks corresponding to manganese or cerium sulfate were observed. This finding is also in agreement with literature data on $\mathrm{SO}_{2}$ storage on alkali metal containing compounds [18, 19].

This result explains the higher resistance of the potassium impregnated catalysts to sulfur poisoning. As long as potassium nitrate is present on the catalyst, it is preferentially converted to potassium sulfate by the $\mathrm{SO}_{2}$ of the gas phase. The residual potassium nitrate is sufficient to enhance the contact of soot and catalyst even at low concentrations, as confirmed by the experiment with different potassium loadings (figure 5). The slow deactivation of the catalyst still taking place can be ascribed to the blockage of the active surface of the catalyst by the formed potassium sulfate.

\section{Conclusions}

Potassium nitrate impregnation was found to increase the activity and stability against sulfur poisoning of cerium based soot oxidation catalysts. The higher activity of the catalyst was attributed to an increased contact between catalyst and soot, which was confirmed by the match of the ignition temperature of soot with the melting point of potassium nitrate. The higher stability 
against sulfur poisoning was ascribed to a protection effect of potassium, as it is getting preferentially sulfatized in comparison to cerium and manganese.

\section{References}

[1] J.P.A. Neeft, M. Makkee and J.A. Moulijn, Chem. Eng. J. 64 (1996) 295.

[2] B.A.A.L. van Setten, J.M. Schouten, M. Makkee and J.A. Moulijn, Appl. Catal. B 28 (2000) 253.

[3] S.J. Jelles, B.A.A.L. van Setten, M. Makkee and J.A. Moulijn, Appl. Catal. B 21 (1999) 35.

[4] B.A.A.L. van Setten, C. van Gulijk, M. Makkee, J.A. Moulijn, G. Huethwohl and C. Kohberg, Top. Catal. 16 (2001) 275.

[5] G. Neri, G. Rizzo, S. Galvagno, A. Donato, M.G. Musolino and R. Pietrapaolo, Appl. Catal. B 42 (2003) 381.

[6] A.L. Carrascull, M.I. Ponzi and E.N. Ponzi, Ind. Eng. Chem. Res. 42 (2003) 692.

[7] V.G. Milt, M.L. Pissarello, E.E. Miró and C.A. Querini, Appl. Catal. B 41 (2003) 397.

[8] D. Uner, M.K. Demirkol and B. Dernaika, Appl. Catal. B 61 (2005) 334.
[9] V.G. Milt, C.A. Querini, E.E. Miró and M.A. Ulla, J. Catal. 220 (2003) 424.

[10] M.L. Pisarello, M.A. Milt, M.A. Peralta, C.A. Querini and E.E. Miró, Catal. Today 75 (2002) 465.

[11] K. Tikhomirov, O. Kröcher, M. Elsener and A. Wokaun, Appl. Catal. B 64 (2006) 72.

[12] A. Setiabudi, J. Chen, G. Mul, M. Makkee and J.A. Moulijn, Appl. Catal. B 51 (2004) 9.

[13] J. Twu, C.J. Chuang, K.I. Chang, C.H. Yang and K.H. Chen, Appl. Catal. B 12 (1997) 309.

[14] R. Flouty, E. Abi-Aad, S. Siffert and A. Aboukaïs, Appl. Catal. B $46(2003) 145$.

[15] A.P. Walker, Top. Catal. 28 (2004) 165.

[16] J.P.A. Neeft, O.P. van Pruissen, M. Makkee and J.A. Moulijn, Appl. Catal. B 12 (1997) 21.

[17] M. Machida, M. Uto, D. Kurogi and T. Kijima, Chem. Mater. 12 (2000) 3158

[18] H.L. Fang, J.C. Wang, R.C. Yu, C.Z. Wan and K. Howden, SAE Paper 2003-01-3245.

[19] C.M. Ingersoll, D.E. Roland, A.M. Kacuba, C.L. Wilkinson and J.M. Berty, Environ. Prog. 22 (2003) 199. 